\title{
術後性蝶形骨洞囊胞による動眼神経麻痺例
}

\author{
石神 瑛亮, 小林 正佳, 竹内 万彦 \\ 三重大学大学院医学系研究科耳鼻咽喉·頭頸部外科
}

【はじめに】副鼻腔囊胞の中で蝶形骨洞囊胞の頻度は比較的低い。蝶形骨洞は視神経，動眼神経，滑車神経， 外転神経と近接するため, 蝶形骨洞に病変が生じると視器障害を発症しやすく, 不可逆的な機能障害を防ぐた め, 早期治療が必要である。今回, 術後性蝶形骨洞囊胞による動眼神経麻疩が, 亜急性期の手術により改善し た例を報告する。【症例】 77 歳女性。20歳時に両側副鼻腔炎で副鼻腔根本術, 60 歳時に左内視鏡下篩骨洞手術 を受けた。初診日 17 日前より左鼻奥の疼痛を自覚した。初診日 4 日前に複視, 左開眼障害を発症し, 近医耳鼻 咽喉科を受診した。CTで左蝶形骨洞囊胞を指摘され，当院当科を紹介された。【既往歴・合併症】無症候性ラ クナ梗塞に対してアスピリン内服中であった。【初診時所見】左眼瞼下垂, 左眼の下転障害・内転障害を認め た。CTで左蝶形骨洞に周囲を圧排する軟部陰影を認め, 蝶形骨洞上外側と中隔の骨欠損を認めた。【治療】入 院日に緊急手術として左蝶形骨洞囊胞を広く開放した。術翌日から左眼瞼下垂, 左眼下転障害・内転障害が改 善した。【考察と結語】蝶形骨洞囊胞は視器障害を併発する頻度が高く, 症状の頻度は, 視力障害, 眼球運動障 害, 眼球突出の順に多いとされている。本例のように, 眼球運動障害は視力障害と異なり, 発症から日数が経 過しても手術により改善する例がある。よって, このような例には日数が経過していても積極的に治療介入す べきである。

キーワード : 蝶形骨洞囊胞, 動眼神経麻痺, 内視鏡下鼻内副鼻腔手術

\section{A Case of Oculomotor Nerve Palsy Caused by a Postoperative Sphenoid Sinus Cyst}

\author{
Eisuke Ishigami, Masayoshi Kobayashi, Kazuhiko Takeuchi
}

Department of Otorhinolaryungology-Head and Neck Surgery, Mie University Graduate School of Medicine

Sphenoid sinus cyst is a relatively rare disease. Since the sphenoid sinus is located close to the optic, oculomotor, trochlear and abduction nerves, a lesion of the sphenoid sinus often induces dysfunction of vision and eye movement. Here we report a case of postoperative sphenoid sinus cyst with oculomotor nerve palsy that was treated with endoscopic sinus surgery to improve eye movement. A 77-year-old woman presented with pain in the left side of the nose that started 17 days before her first visit to our hospital. She developed diplopia and ptosis of the left side 4 days before this visit. CT showed a left sphenoid sinus cyst. Her history included left extranasal sinus surgery for sinusitis at age 20 and left endoscopic endonasal ethmoidectomy at age 60. She was taking aspirin for asymptomatic lacunar infarction. Ptosis, downturn and adduction disorder of the left eye were observed. CT showed a soft tissue shadow filling her left sphenoid sinus, and the septum of the sphenoid sinuses and superolateral bone of the left sphenoid sinus were eroded. We opened the left sphenoid sinus cyst widely in 
endoscopic endonasal sinus surgery as an emergency operation on the day of admission. On the day after surgery, ptosis and left ocular movement disorder were improved. A sphenoid sinus cyst causes visual dysfunction in the frequency order of visual disorder, ocular movement disorder, and proptosis.

Unlike eyesight disorders, eye movement disorders may be improved by surgery several days after onset, as in this case. Thus, positive surgical intervention should be performed in such cases, even at several days after onset.

Key words : sphenoid sinus cyst, oculomotor nerve palsy, endoscopic sinus surgery

(2019年9月 18 日受稿, 2019 年 12 月 23 日受理)

\section{はじめに}

副鼻腔囊胞の中で蝶形骨洞囊胞の頻度は比較的低い。 発生部位として，術後性では蝶形骨洞が $1 \% ，$ 篩骨洞と 蝶形骨洞にわたるものが $6 \%$ とされており，原発性では 蝶形骨洞が $8 \%$, 篩骨洞と蝶形骨洞にわたるものが $14 \%$ と報告されている ${ }^{1)}$ 。蝶形骨洞は解剖学的に視神経, 動 眼神経, 外転神経, 滑車神経と近接しており, 蝶形骨洞 囊胞は視器障害を合併しやすい。よって, 不可逆的な変 化をさけるため, 早期の治療介入が必要である。今回, 術後性蝶形骨洞囊胞による動眼神経麻瘏が覀急性期の手 術で改善した例を経験したので報告する。

\section{症例}

\section{症例：77歳女性}

主訴 : 左鼻痛, 開眼障害, 複視

現病歴：初診日の 17 日前より左鼻奥の疼痛を自覚し た。初診日 4 日前に複視, 左開眼障害があり, 近医総合 病院を受診し, CTで左蝶形骨洞囊胞を指摘され，当院当
科へ紹介された。

既往歴: 慢性副鼻腔炎に対して20歳時に両側副鼻腔根 本術を, 60 歳時に左内視鏡下鼻内篩骨洞手術を受けた。 また，無症候性ラクナ梗塞に対してアスピリンを服用し ている。

初診時所見：鼻内所見では左篩骨洞は過去の手術によ り隔壁は削除されており, 左蝶篩陥凹壁が膨隆していた。 膿汁などの液体の流出は認めなかった。視力は右 1.2 , 左 0.9 と障害はなく, 視野狭窄も認めなかった。左眼瞼下垂 があり，左眼の眼球運動障害（内転障害, 下転障害）を 認めた（図 1)。Hess赤緑試験でも左眼の内転障害, 下転 障害を反映しており，この試験では上転障害も認められ た（図2）。

初診時の副鼻腔単純CT画像:左蝶形骨洞に軟部陰影を 認め, 周囲を圧迫するように拡大していた（図3）。水平 断で蝶形骨洞中隔の骨欠損, 冠状断で上外側の頭蓋底の 骨欠損を認めた。

左術後性蝶形骨洞囊胞による左動眼神経麻痺と診断と した。発症後 17 日経過し, 視機能障害も呈しており, 早

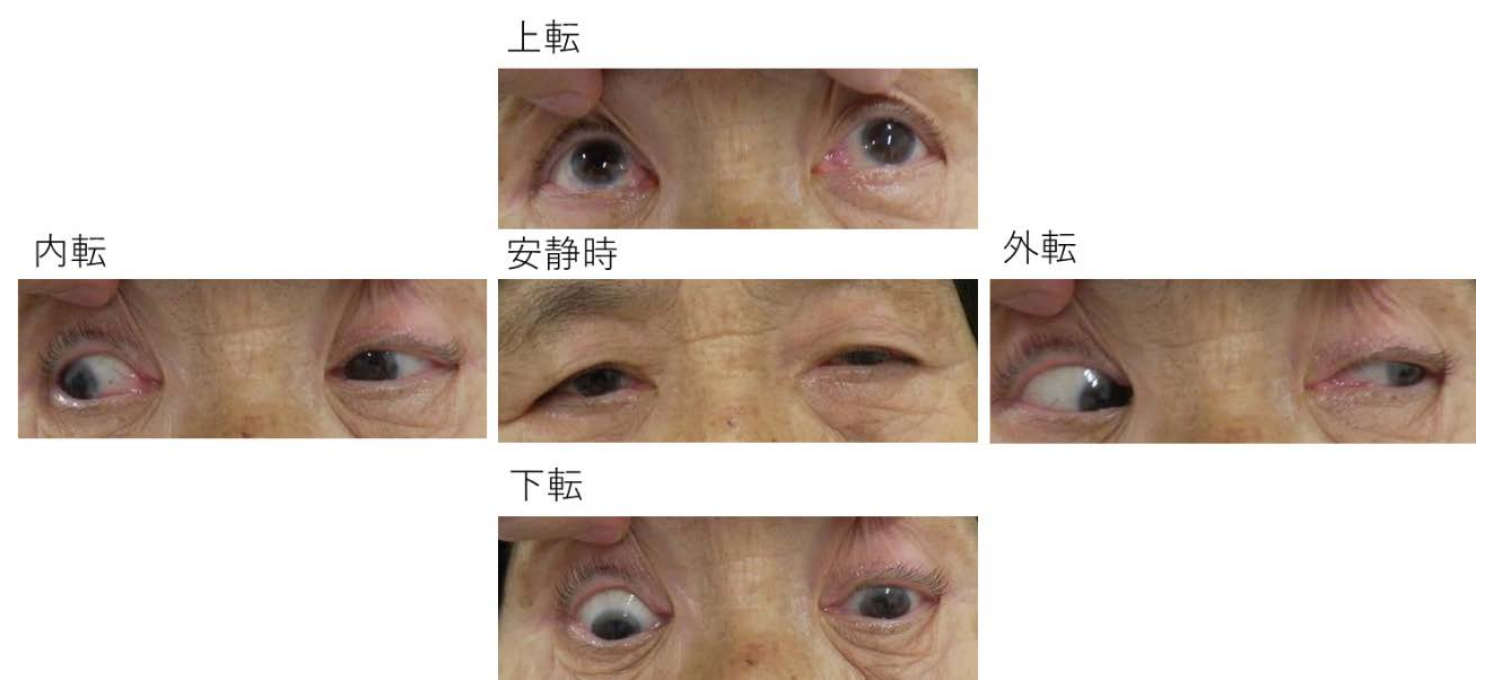

図1 初診時眼球運動所見。左眼瞼下垂，左眼の眼球運動障害（内転障害，下転障害）を認める。 
左 眼

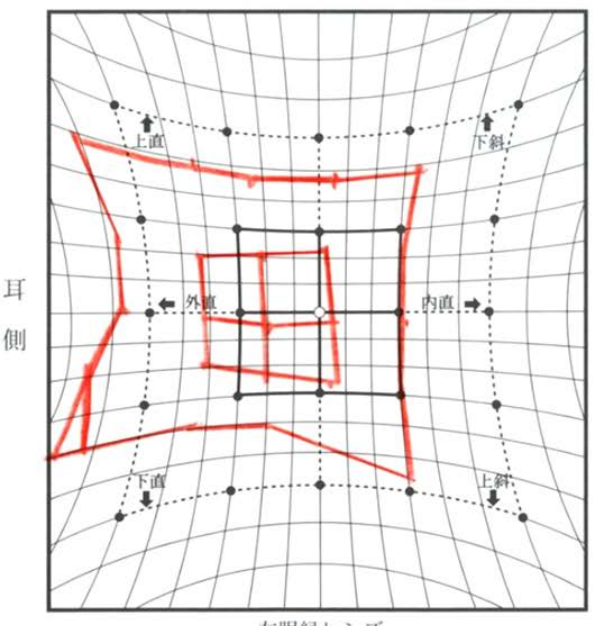

左眼緑レンス
右 眼

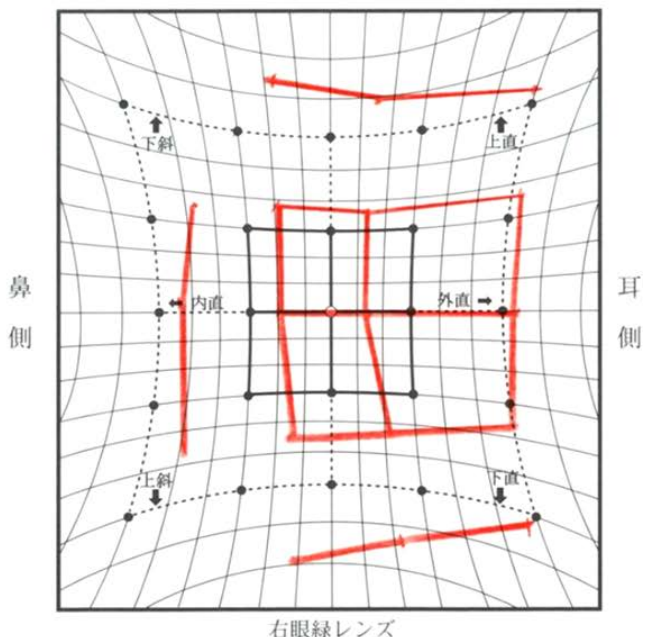

図2 初診時Hess赤緑試験。左眼の内転障害, 下転障害, 上転障害を認める。
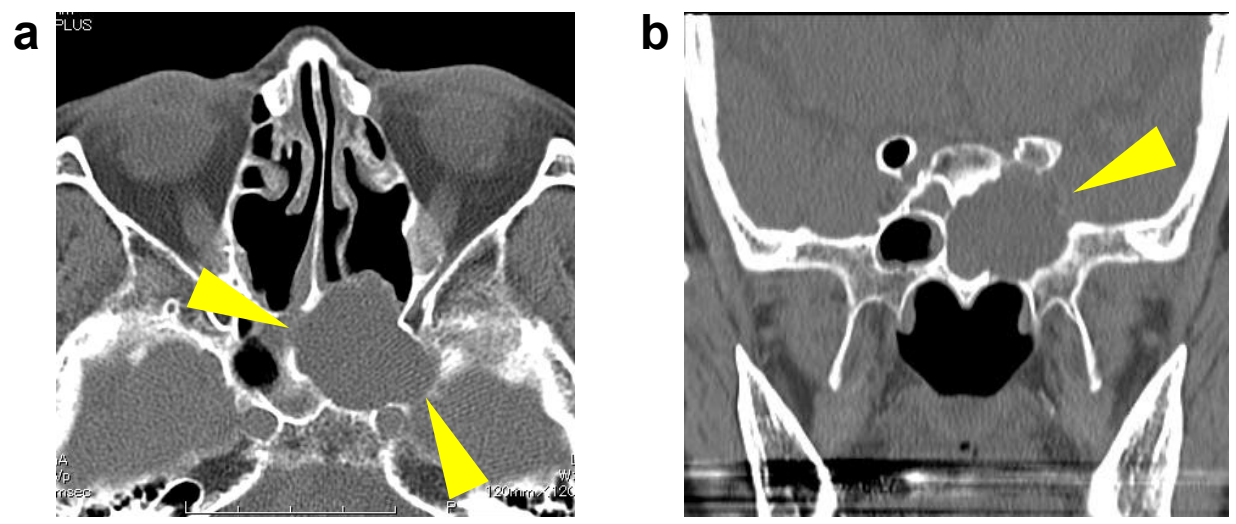

図3 初診時単純CT。左蝶形骨洞に軟部陰影を認め, 周囲を圧迫するように拡大している。a:水平断。水平断で蝶形骨洞中隔の 骨欠損を認める。 b : 冠状断。冠状断で上外側の頭蓋底の骨欠損を認める。

期介入が望ましいと考え，当科受診日に緊急で左内視鏡 下鼻副鼻腔手術を施行した。

治療：手術は全身麻酔下，逆トレンデレンブルグ体位 で施行した。左穊骨洞は開放されており, 左中鼻道から 囊胞壁を確認できたが，より囊胞壁を広範囲に確認しや すかった左上鼻道経由で囊胞を開放した。囊胞内容液は 黄色漿液性で, 膿汁は認めなかった。襄胞を開放し, 左 蝶形骨洞内の骨欠損部の瘦孔, 髄液漏, 硬膜露出は無く, 壁が粘膜で被われていることを確認した。左蝶篩陥凹の 囊胞壁も削除し, 広く囊胞を開放した。確実に襄胞再発 を予防する目的で, 右鼻膑内からも rescue flap incision （蝶形骨洞自然口内側縁から鼻中隔後部まで水平に入れ る粘膜切開）を入れ ${ }^{2)}$ ，右蝶形骨洞を開放し，蝶形骨洞 中隔を削除し，左右の蝶形骨洞を単洞化した。右篮骨洞 ルートも開放した。なお，アスピリン内服中であったた
め, 左右の蝶形骨洞を単洞化する際に蝶口蓋動脈後鼻中 隔枝を損傷しないようにrescue flap incisionを入れ，電気 メスで先行止血を施行した。また，両側蝶形骨洞・右篩 骨洞開放部縁は 10 万倍希釈エピネフリン含有綿での圧迫 止血，電気メスでの凝固止血を施行した。さらに麻酔科 医に依頼し，全身循環に支障を来さない範囲で降圧コン トロールをしてもらい, 術中の収縮期血圧 $100 \mathrm{mmHg}$ 未 満で施行した。手術時間 65 分, 出血量は $10 \mathrm{ml}$ であった。 術後経過：経過は良好で，手術直後より自覚症状は消 失しており, 手術翌日には眼瞼下垂, 眼球運動障害は改 善し, 眼球運動の左右差は消失した。術後 5 日目に退院 した（図4, 図5)。

現在術後 1 年経過し, 蝶形骨洞襄胞・炎症の再燃や視 機能障害はなく経過している（図6，図7）。 

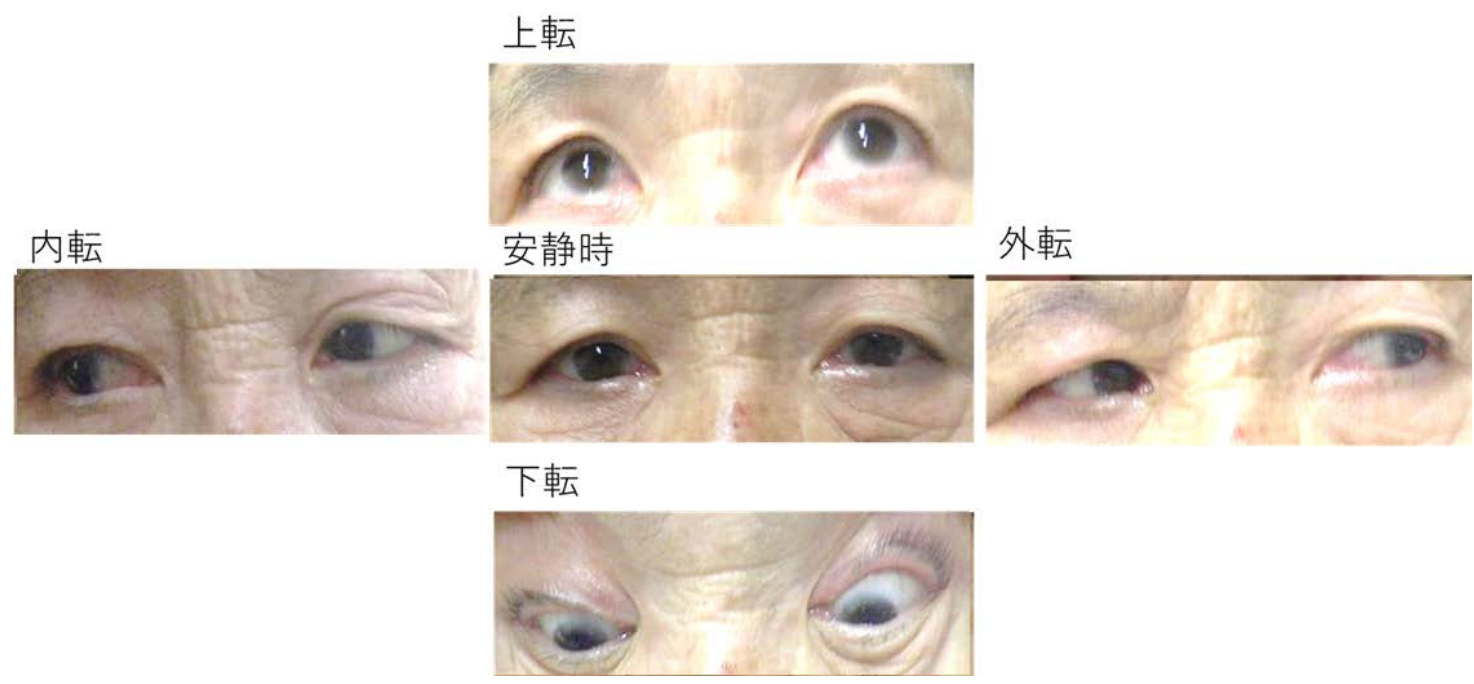

図4＼cjkstart術後1日目の眼球運動所見。左眼瞼下垂，左眼の眼球運動障害を認めない。

左 眼

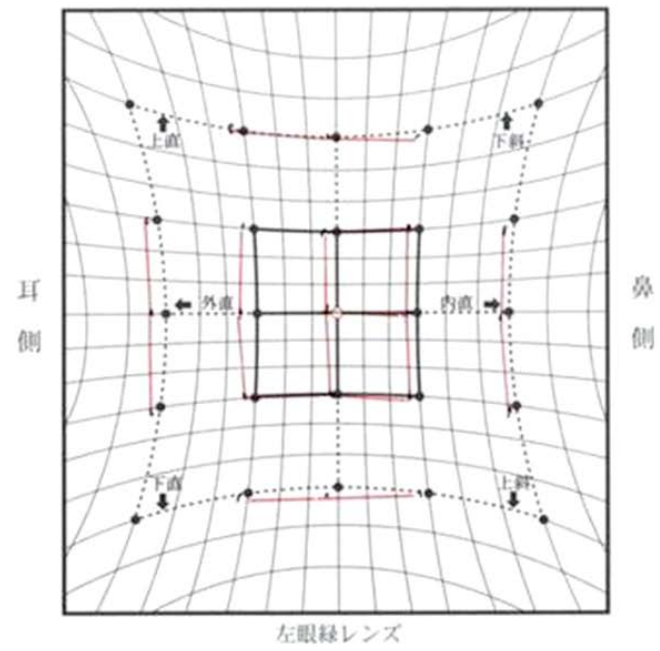

右 眼

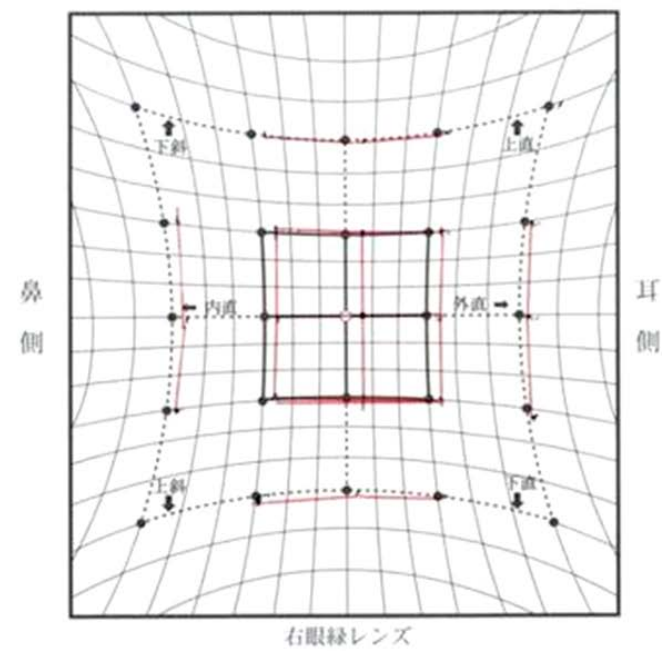

図5 術後5日目のHess赤緑試験。左眼球運動障害を認めない。

a

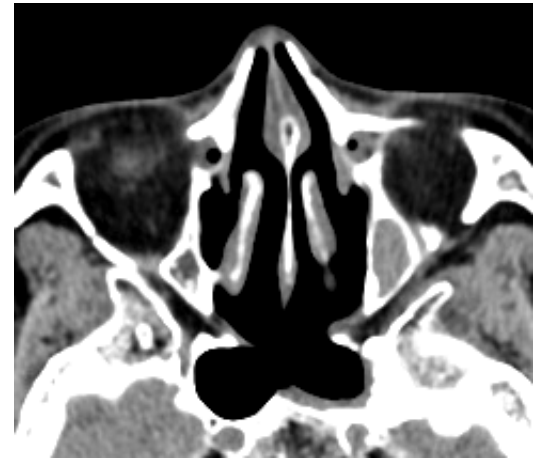

b

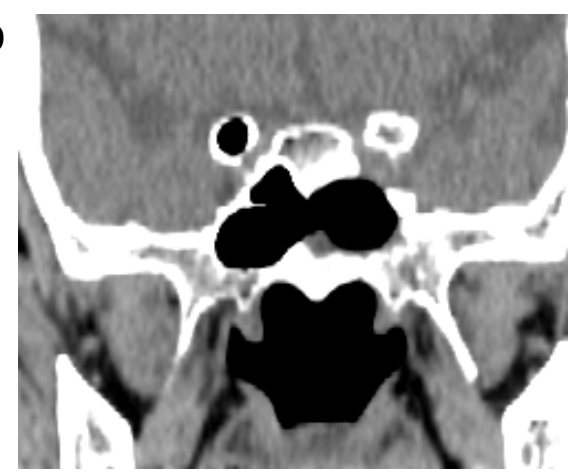

図6 術後 1 年経過時点の単純 $\mathrm{CT}$ 。左右の蝶形骨洞は単洞化状態のままで, 内部に陰影は認めない。 $\mathrm{a}$ : 水平断。 $\mathrm{b} ：$ 冠状断 


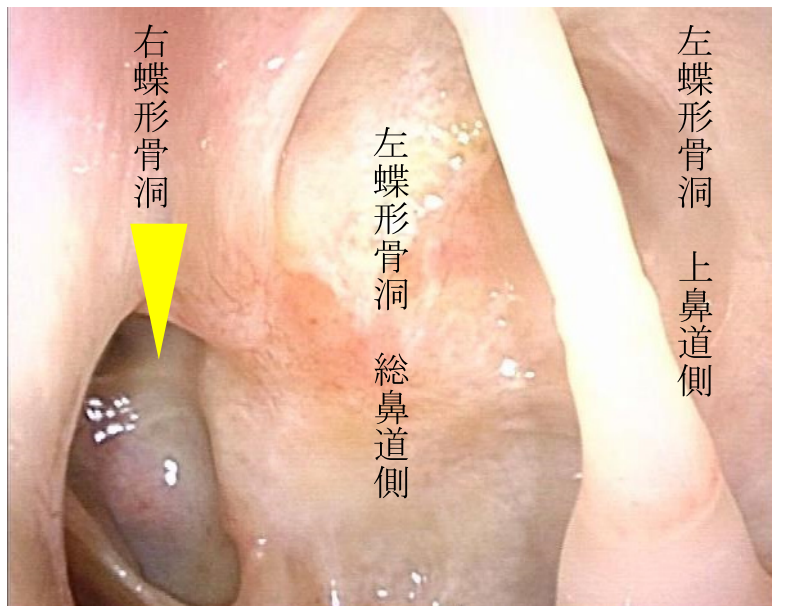

図7 術後 1 年経過時点の鼻内内視鏡所見。左右の蝶形骨洞 は単洞化状態を維持しており, 大きく開放されている。

\section{考察}

副鼻腔囊胞の原因としては術後性が80～90\%と最も多 く, 原発性は 10～20\%，外傷性・歯原性が数\% $\%^{3.4)}$ と報告 されている。部位別発生頻度としては, 術後性では上顎 洞が $72 \%$ と多くを占め, 次いで篩骨洞が $9 \%$, 前頭洞が $4 \%$ ，蝶形骨洞が $1 \%$, 前頭洞・篩骨洞にわたるものが $8 \%$ ，篩骨洞・蝶形骨洞にわたるものが $6 \%$ とされており， 原発性では穊骨洞が $32 \%$ と最も多く, 次いで前頭洞が $22 \%$, 蝶形骨洞が $8 \%$, 前頭洞・穊骨洞にわたるものが $24 \%$ ，穊骨洞・蝶形骨洞にわたるものが $14 \%$ と報告され ており ${ }^{1)}$, 蝶形骨洞囊胞の発生頻度は低い。しかし, 蝶 形骨洞は解剖学的に視神経, 動眼神経, 外転神経, 滑車 神経に近接しており, 蝶形骨洞囊胞による視器障害の頻 度は高く, 視力障害が $69 \%$, 眼球運動障害が $34 \%$, 眼球 突出が $21 \%{ }^{5)}$ と報告されている。眼球運動障害について は, 動眼神経, 外転神経, 滑車神経の順に障害されやす いとされており ${ }^{5}$, これは前床突起に近い順と一致してい る。蝶形骨洞の発育が良く, 前床突起まで含気腔拡大が 進むと，蝶形骨洞と動眼神経の境界が薄い骨壁となるた め, 震胞による圧迫を受けやすいためとされる ${ }^{6)}$ 。また, 蝶形骨洞の後部の骨壁に沿って走行するのは動眼神経の みであり, 霊胞が後外側へ伸展した場合, 神経圧迫を受 けやすいとされる7)。本症例に扔いては蝶形骨洞囊胞の 後外側への伸展を認め, 前床突起内の蜂巣にも陰影を認 めたが，上眼窩裂には異常を認めなかったため，動眼神 経単独麻痺を来したと考えられる。

視器障害の予後について, 視力障害と眼球運動障害で 分けて考察する。視力障害については, 視力低下であれ ば発症から 2 日以内, 光覚消失まで至っていれば発症か
ら 24 時間以内に手術を行うことで予後良好 ${ }^{8)}$ と報告され ている。術前視力が 0.1 以上であれば手術までの期間に 関わらず予後良好, 指数弁以下であれば発症後 24 時間以 内の手術で予後良好だが 8 日以上経過すると予後不良と する報告9 もあるが, 術前の視力障害の程度, 発症から 手術までの期間が視力の予後に大きく関わるとする報告 が多い。眼球運動障害については，視力障害より予後良 好とされ, 蝶形骨洞・篩骨洞囊胞での検討では改善率 $83 \%$ と報告されている ${ }^{10)}$ 。また，発症後6力月経過した時点で の手術で改善した報告例もある ${ }^{11}$ 。これは視神経と動眼 神経・外転神経・滑車神経の髄鞘を構成する細胞の違い が原因と考えられる。視神経ではこれが希突起膠細胞か らなり, 変性時にほとんど増生しないが, 動眼神経・外 転神経・滑車神経ではSchwann細胞により髄鞘が構成さ れており, 変性時に増生する。このため, 視神経は障害 を受けた場合に不可逆的になりやすいと考えられる ${ }^{9,10,122}$ 。 副鼻腔囊胞による神経障害の原因には，神経の機械的圧 迫，圧迫による神経栄養血管の循環障害，神経への炎症 波及などがある ${ }^{9,11,13)}$ 。圧迫が長期化した例や炎症波及が ある例では圧迫解除だけでは術後すぐに症状改善がみら

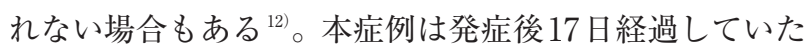
が，手術翌日には改善を認めた。神経の圧迫による要因 が大きく, 神経への炎症波及はわずかであったと考える。

画像所見についてはCT, MRIを撮影するのが一般的で ある。CTでは本症例のように, 等吸収一低吸収の内部均 一な除影を蝶形骨洞に認め, 骨壁の圧排・菲薄化・尔損 を認める。本症例では, CTでこれらの所見と既往歴, 臨 床所見より術後性蝶形骨洞霊胞と診断し，早急な介入を 優先したため, MRI撮影は行っていないが，一般にMRI で囊胞の信号強度はT1強調像で低〜中等度，T2で高信 号となる。内部の粘稠度が増すとT1強調像で信号強度が 増強し, T2 強調像で信号強度が低下寸ることがある。同 時にMRAを撮影することで, 脳動脈瘤や脳血管疾患によ る動眼神経麻痺を除外する一助となる。また，蝶形骨洞 に襄胞がある場合, 蝶形骨洞と内頸動脈の間の骨構造が 欠損している場合があり，術中に内頸動脈が露出する可 能性があるため, MRI, MRAで蝶形骨洞と内頸動脈の接 している部分を確認し，内頸動脈破裂に備えて脳神経外 科との連携を図っておく必要がある。

副鼻脉囊胞の手術治療は発生部位により経鼻内法, 経 上顎洞法, 鼻外切開法があり, 囊胞壁を全摘するか囊胞 を広く開放する必要がある。穊骨・蝶形骨洞囊胞は経鼻 的に囊胞壁を全摘することは困難なため，内視鏡下鼻副 鼻腔手術が主体となる ${ }^{14)}$ 。開放のポイントとして，本症 例では，再発予防をより確かなものとするために，上鼻 
道, 中鼻道, 総鼻道の 3 つのルートから囊胞壁・蝶形骨 洞を広く開放し，さらに左蝶形骨洞に限局する襄胞で あったが，左右の蝶形骨洞を単洞化することで広くドレ ナージルートをつけた。さらに, この際にrescue flap incisionを入れて, 蝶口蓋動脈後鼻中隔枝を含む粘膜を削 除する骨から剥離して，動脈性出血の予防も図った。

今回, 眼球運動障害に対する早期対処を優先し，抗血 小板薬服用下であったが緊急手術を施行した。前述のご とく眼球運動障害が視力低下より予後良好という過去の 報告はあるものの，眼球運動障害発症後4 日経過（疼痛 発症後17日）していて，これ以上待機することによる不 可逆的な後遺障害残存を懸念しての判断であった。高齢 者の増加に伴い, 今後, 抗血小板薬, 抗凝固薬を服用さ れている患者は増加していくと思われる。しかしながら， 日本循環器学会のガイドライン ${ }^{15)}$ では「緊急手術時の出 血性合併症に準じた対処」を行うことはクラスIIa’と記載 があるのみであり，外科手術における抗血小板薬，抗凝 固薬の休薬に関して, 明確なエビデンスのある指針は示 されていない。よって現時点では, 抗血小板薬・抗凝固 薬内服下で緊急手術は, 術者自身が出血のリスクを考慮 し，出血を少なくする方法と工夫をするのが肝要である。 本症例では術中体位と麻酔科医と連携した術中血圧のコ ントロール，電気メスや血管収縮薬含有綿などの手術器 具, 材料の工夫で対処できた。また, 出血を避けるため に侵襲的操作を減らす必要があった一方で，再発予防を より確実なものとするため, 左右の蝶形骨洞単洞化した が，その際には蝶口蓋動脈後鼻中隔枝の損傷による出血. を避けるためrescue flap incisionを入れる工夫をした。 今後も抗血小板薬・抗凝固薬の内服下で手術を必要とす る症例は増加すると考えられるので，元々術野の広さが 限られている内視鏡下手術ではこれらの工夫をこらすこ とで術中の安全と術後出血予防を図ることを念頭におい ておくべきと考える。

\section{まとめ}

1）手術により改善した術後性蝶形骨洞囊胞による動眼 神経麻瘦例を経験した。

2）亜急性期であっても手術により視器障害が改善する 可能性があり, 眼球運動障害では視力障害よりも予後 が良好である。

3）発症から日数が経過していても, 副鼻胿霬胞による視 器障害がある場合は積極的に除圧手術を行うべきで あると考えた。

4）抗血小板薬内服下の鼻内内視鏡手術においては，術
中体位，血圧コントロールによる出血予防を行い，手 術操作については電気メスでの先行止血, 切断面の凝 固止血を徹底し, 操作する箇所を極力少なくすること が求められる。

\section{参考文献}

1）藤森正登，中川雅文，芳川 洋：当教室における副 鼻胿囊胞の検討。耳鼻 $1992 ； 38 ： 247-251$.

2) 田中秀峰：経蝶形骨洞アプローチ. 中川隆之 編. 内視鏡下鼻副鼻腔·頭蓋底手術 $\mathrm{CT}$ 読影と基本手技 第2版. 医学書院；2019：p.233-243.

3）飯沼寿孝:副鼻腔囊胞概論. JOHNS 1989;5:25-32.

4）坂井田寛，小林正佳，湯田厚司，他：原発性副鼻沿 囊胞の臨床的検討.耳鼻臨床 $2005 ； 98 ： 377-380$.

5）山内盛雄, 太田文彦, 宮前雅明：蝶形骨洞囊胞一本 邦における病像の特異性について一. 耳鼻臨床 1980; $173: 811-821$.

6）笹森史朗, 渡邊敏明, 大和田健司：動眼神経麻瘏を 主症状とした後部副鼻腔囊胞の 1 症例。耳喉頭頸 $1993 ; 65$ : 391-394.

7) Norman PS, Yanagawa E : Mucocele of the sphenoid sinus. Arch Otolaryngol $1964 ; 79$ : 646-652.

8）蔦 佳尚, 上川保廣, 友田幸一, 他：眼症状を呈し た副鼻腔囊胞の検討。耳鼻臨床 $1991 ; 84: 945-951$.

9）飯村慈朗，蒲 伸泰，平林秀樹，他：視力障害を伴 う後部副鼻腔囊胞の臨床的検討.耳展 $2007 ； 50$ ： 404-409.

10）岡 正倫, 安松隆治, 吉川沙耶花, 他：当科におけ る篩骨洞・蝶形骨洞囊胞の臨床的検討。耳鼻 2009 ; $55: 142-146$.

11）岡本朋代，児玉 悟，鈴木正志：蝶形骨洞襄胞によ る動眼神経麻痺で発症6ヶ月後に手術にて改善のみ られた 1例。耳鼻臨床 2011；104：331-334.

12）嶋根俊和, 古矢彩子, 森本雅太, 他：眼症状を併発 した副鼻腔囊胞 5 例の臨床的検討。耳展 $2006 ； 49$ ： $124-130$.

13）春日井滋，小宅大輔，肥塚 泉，他: 動眼神経不全麻 痺を呈した蝶形骨洞炎。耳鼻臨床 2009; 102:939-943.

14）春名眞一：副鼻腔囊胞性疾患一内視鏡手術一. 頭頸 部外科 $2008 ; 18: 115-117$.

15）日本循環器学会. 循環器病ガイドラインシリーズ 2015年版：循環器疾患に打ける抗凝固・抗血小板 療法に関するガイドライン (2009年改訂版).http:// www.j-circ.or.jp/guideline/index.htm (2019年9月閲覧) 